\title{
TOGAF for designing the enterprise architecture of LAZISMU
}

\author{
Jefree Fahana ${ }^{1, *}$, Ahmad Azhari ${ }^{2}$ \\ Informatics Department, Universitas Ahmad Dahlan, Yogyakarta, Indonesia \\ ${ }^{1}$ jefree.fahana@tif.uad.ac.id *; ${ }^{2}$ ahmad.azhari@tif.uad.ac.id \\ * corresponding author

\begin{tabular}{ll}
\hline ARTICLE INFO & ABSTRACT \\
& \\
& LAZISMU as an amil zakat institution has an important role in collecting and managing \\
zakat for public welfare. The existence of Law No. 23 of 2011 and the Minister of Religion \\
Article history & Regulation No. 333 of 2015 on Guidelines for Granting Permits for the Establishment of \\
Received August 30, 2018 & Zakat Institutions requires that the management of zakat, infaq, and sadaq (ZIS) funds be \\
Revised September 26, 2018 & transparent, accountable and prioritize professional principles. For this reason, there needs \\
Accepted October 7, 2018 & to be support from information systems and information technology to achieve these business \\
goals. Information systems and technology will be utilized optimally if the development is \\
Keywords \\
LAZ \\
aligned with the business objectives of the organization. Enterprise Architecture (EA) is a \\
bridge to harmonize the business needs of an organization with Information Systems and \\
Information Technology. Enterprise architecture planning at the LAZ has been designed using \\
The Open Group Architecture Framework (TOGAF) with Architecture Development \\
Method (ADM). Data collection is done by interviewing and making direct observations of \\
the organization. Analysis tools used are the Unified Modelling Language (UML) method \\
and the Value Chain method. The results of this study are blue print business architecture, \\
data architecture, application architecture so that it can support the business processes that \\
exist in LAZISMU.
\end{tabular}

This is an open access article under the CC-BY-SA license.

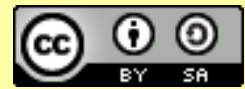

\section{Introduction}

Based on Indonesian Law Number 23 of 2011 on Zakat, each zakat management must be carried out by official government institutions and zakat institutions that have been approved by the government. This law prohibits any person or institution from withdrawing zakat from the community. The existence of this Act gives authority to the Zakat Institution to be able to collect funds optimally from the community. Because it is stated for everyone to deliberately collect zakat funds from the public, they will be subject to fines and criminal penalties [1]. In addition, the Government of Indonesia issued several regulations including the Minister of Religion Regulation No. 52 of 2014 on Requirements and Procedures for Calculating Mal Tithes and Zakat Fitrah and Utilizing Zakat for Productive Enterprises and Minister of Religion Decree No. 333 of 2015 on Guidelines for Granting Permits for the Establishment of Amil Institutions Zakat [2], [3].

Indonesia's zakat potential from year to year has experienced a significant increase. References [4] states that in 2012 the potential of zakat in Indonesia reached 3.4\% of the total gross domestic product (GDP), equivalent to 217 trillion rupiah, while in 2015, based on the results of the research division of the Center for Strategic Studies of the National Zakat Agency (PUSKAS BAZNAS) reached IDR 286 trillion [5].

Based on the above conditions, Reference [6] states that the role of LAZ in the efforts to collect and utilize zakat for public welfare becomes important and becomes a necessity by promoting the principles of good corporate governance.

The existence of support from information systems and information technology can help realize organizational goals [7], [8]. In organizational management, reference [9] describes three strategic 
roles of information systems, including operational management, to support decisions, and to support the creation of competitive advantages. Planning both in building an information system and information technology of an organization according to [10] becomes very necessary to be done until the organizational strategic objectives are achieved. Preparation of Enterprise Architecture (EA) can be one solution to create good planning. The use of EA will result in harmony between the business needs of the organization and information systems and technology. The ability to communicate with customer-oriented and the ability to provide integrated and economical services is the reason for the use of EA is very relevant and needed in an organization.

Research on the TOGAF Framework has been widely applied to organizations or companies [11][14]. References [11] have proposed five phases TOGAF in PT. Pelabuhan Indonesia II to compile an information system strategy proposal and a planning document for the business process Reporting System in the goods service section. Other research work has been done by [12], TOGAF has been successfully applied on Development of Indonesian Scientific Journal Management System with a sequential transformative strategy approach. Blueprint for information technology development in the form of sketches of planning and application of Information Technology at Garut State Vocational High School (SMKN) which refers to national education standards using value chain analysis [13]. TOGAF ADM is also able to help identify in full and detailed business processes that occur at the Bumigora Mataram College of Information and Computer Management [15].

The use of TOGAF in this study focuses on building Enterprise Architecture (EA) at Amil Zakat Institutions (LAZ) using ADM. The results of this study are in the form of blueprints for system development and information technology. To limit this research, researchers only used 5 stages from 9 stages in the TOGAF ADM framework namely Premiliary (Preparation), Vision Architecture, Business Architecture, SI Architecture, IT Architecture, while for LAZ to be studied is LAZNAS LAZISMU especially LAZISMU Representative Office in the Special Province of Yogyakarta.

\section{Method}

This paper uses two research methods containing methods of data retrieval and analysis. Data retrieval is done in several ways, namely interviews, observation and literature study. The analysis adopts the stages of AE preparation in the ADM TOGAF, namely the Preparation Phase, Architectural Vision, Business Architecture, Architectural Information Systems. The preparation phase identify the scope affected by the application of Enterprise Architecture to be built. Among the affected organizational units include:

- The core unit of the organization affected: Organizational units in LAZISMU Special Region of Yogyakarta

- Supporting Units of affected organizations: Muhammadiyah Regional Leader Special Region of Yogyakarta, LAZISMU Center, LAZISMU Region

- Affected expansion units: National Baznas Special Region of Yogyakarta, Ministry of Religion Special Region of Yogyakarta

- Affected community units: Muzaki (Donors) and Mustahik (beneficiaries)

In addition, in this phase also declared architectural principles refer to management principles. The principle of this architecture will be used as a reference in the preparation of enterprise architecture. Table 1 shows a catalog of architectural principles. It consists of ten principles such as Islamic Shari'a, Trusteeship, Benefit, Justice, Legal Certainty, Integration, Accountability, Professional, Transparency, and Synergy. 
Table 1.

Architectural Principle Catalogs

\begin{tabular}{ccc}
\hline No. & Architectural Principle & Principle Catalogs \\
\hline 1 & Islamic Shari'a & Business Principle \\
\hline 2 & Trusteeship & Business Principle \\
\hline 3 & Benefit & Business Principle \\
\hline 4 & Justice & Business Principle \\
\hline 5 & Legal Certainty & Business Principle \\
\hline 6 & Integration & Data and Applications Principle \\
\hline 7 & Accountability & Business Principle \\
\hline 8 & Professional & Business Principle \\
\hline 9 & Transparency & Business Principle \\
\hline 10 & Synergy & Business Principle \\
\hline
\end{tabular}

The phase architecture vision, scope of LAZISMU Special Region of Yogyakarta activities will be presented in the Value Chain chart. The results of this phase are grouping activities into two categories namely main activities and supporting activities. Table 2 shows the chart of the Value Chain Lazism of the Special Region of Yogyakarta.

Table 2.

Activity of Value Chain LAZISMU Special Region of Yogyakarta

\begin{tabular}{|c|c|c|c|c|c|}
\hline \multirow{4}{*}{$\begin{array}{c}\text { Supporting } \\
\text { Activities }\end{array}$} & \multicolumn{5}{|c|}{ Administrative Management } \\
\hline & \multicolumn{5}{|c|}{ Financial Management } \\
\hline & \multicolumn{5}{|c|}{ Facility and Infrastructure Management } \\
\hline & \multicolumn{5}{|c|}{ Public Relations and Publications Management } \\
\hline \multirow{2}{*}{$\begin{array}{c}\text { Main } \\
\text { Activities }\end{array}$} & (Inbound) & (Processing) & (Outbound) & Marketing and Sales & Services \\
\hline & $\begin{array}{l}\text { ZISKA Funds } \\
\text { Collection }\end{array}$ & $\begin{array}{l}\text { ZISKA Fund } \\
\text { Distribution }\end{array}$ & $\begin{array}{c}\text { Use of ZISKA } \\
\text { Funds }\end{array}$ & $\begin{array}{c}\text { Preparation of } \\
\text { Reports and } \\
\text { Publications }\end{array}$ & $\begin{array}{c}\text { Mustahik and } \\
\text { Muzaki } \\
\text { coaching } \\
\end{array}$ \\
\hline
\end{tabular}

This paper aims to produce the design enterprise architecture. Therefore, the result of business architecture phase and system architecture will be discussed in the following section.

\section{Result and Discussion}

In this section, it is explained by the results of research. There are several parts: phase architecture vision, business phase architecture and phase information system architecture. This phase defines the initial conditions of business architecture, and determines organizational structures, services and business models or desired business activities based on existing business processes in the organization. Based on the Value Chain activity, the Organizational Unit and Functions, Business Process LAZISMU Special Region of Yogyakarta can be described in Table 3.

In the business architecture phase, the information system architecture activity was developed. Information system architecture in this stage consists of data architecture and application architecture that will be used by the organization. Table 4 shows the data requirements of business functions and business processes. It also describes the method of Create, Read, Update, and Delete (CRUD) which used in each business functions and entity. While organizational application requirements are shown in Table 5. It describes about applications requirements on each business functions. 
Table 3. Organizational Unit and Function, Business Process LAZISMU Special Region of Yogyakarta

\begin{tabular}{|c|c|c|}
\hline Organizational Unit & Business function & Business Process \\
\hline Sharia Board & $\begin{array}{l}\text { Supervision, direction, and making } \\
\text { decisions on the management of ZISKA } \\
\text { funds to fit syar'i }\end{array}$ & $\begin{array}{l}\text { Approved the annual monthly budget plan, } \\
\text { making decisions on managing ZISKA funds } \\
\text { to fit }\end{array}$ \\
\hline Supervisor Board & $\begin{array}{l}\text { Supervision of the management of } \\
\text { ZISKA funds }\end{array}$ & $\begin{array}{l}\text { Approved the annual monthly budget plan, } \\
\text { overseeing the management of ZISKA funds }\end{array}$ \\
\hline Managerial Board & $\begin{array}{l}\text { Planning, Implementation, Coordinating } \\
\text { in the collection, distribution and } \\
\text { utilization of ZISKA funds; }\end{array}$ & $\begin{array}{c}\text { Compile a draft annual budget, } \\
\text { Prepare a program plan for collecting, } \\
\text { distributing and utilizing ZISKA funds, } \\
\text { Evaluating the implementation of ZISKA } \\
\text { funds collection, distribution and utilization } \\
\text { programs, } \\
\text { Staff recruitment and coaching }\end{array}$ \\
\hline Fundraising Division & $\begin{array}{l}\text { The implementation of the ZISKA fund } \\
\text { raising program }\end{array}$ & $\begin{array}{l}\text { Develop and implement a fund raising } \\
\text { strategy } \\
\text { Identification of muzakki and prospective } \\
\text { muzaki or donors (individuals and } \\
\text { institutions) } \\
\text { Building communication with muzakki and } \\
\text { prospective muzaki or donors (individuals } \\
\text { and institutions) }\end{array}$ \\
\hline Distribution Division & $\begin{array}{c}\text { The program for distributing ZISKA } \\
\text { funds }\end{array}$ & Distribution of ZISKA fundsx \\
\hline Utilization Division & $\begin{array}{c}\text { Implementation of the ZIS fund } \\
\text { utilization program }\end{array}$ & Carry out the program for utilizing ZIS funds \\
\hline Administration Division & Administration management & $\begin{array}{l}\text { Create and inventory documents and activity } \\
\text { proposals }\end{array}$ \\
\hline Finance Division & Finance management & $\begin{array}{l}\text { 1. Data collection on ZISKA fundraising } \\
\text { 2. Prepare reports on raising and utilizing } \\
\text { ZISKA funds }\end{array}$ \\
\hline $\begin{array}{c}\text { Facilities and } \\
\text { Infrastructure Division }\end{array}$ & Infrastructure management & $\begin{array}{l}\text { Procurement, maintenance and inventory of } \\
\text { facilities and infrastructure }\end{array}$ \\
\hline $\begin{array}{l}\text { Public Relations and } \\
\text { Publications Division }\end{array}$ & $\begin{array}{l}\text { Public relations and publications } \\
\text { management }\end{array}$ & $\begin{array}{l}\text { 1. Cooperating with related institutions } \\
\text { 2. Build effective communication with } \\
\text { muzaki / regular donors } \\
\text { 3. Establish effective communication with } \\
\text { mustahik / beneficiaries } \\
\text { 4. Conduct publications in the mass media, } \\
\text { electronics and social media }\end{array}$ \\
\hline
\end{tabular}


Table 4. Data Entity Based on Business Functions

\begin{tabular}{|c|c|c|c|c|c|c|c|c|c|c|c|c|}
\hline Function & $\stackrel{0}{0}$ & 起 & 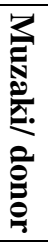 & : & 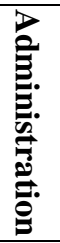 & 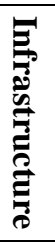 & 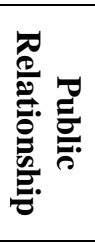 & 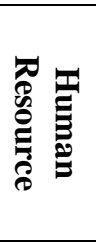 & 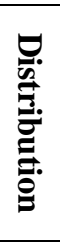 & 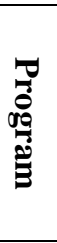 & 高 & 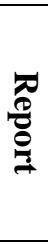 \\
\hline $\begin{array}{c}\text { Supervision, direction, and } \\
\text { making decisions on the } \\
\text { management of ZISKA funds to } \\
\text { fit syar'i }\end{array}$ & $\mathrm{R}$ & & & $\mathrm{R}$ & & & & & & & & $\mathrm{R}$ \\
\hline $\begin{array}{l}\text { Supervision of the management } \\
\text { of ZISKA funds }\end{array}$ & $\mathrm{R}$ & & & $\mathrm{R}$ & & & & & $\mathrm{R}$ & $\mathrm{R}$ & & $\mathrm{R}$ \\
\hline $\begin{array}{l}\text { Planning, Implementation, } \\
\text { Coordinating in the collection, } \\
\text { distribution and utilization of } \\
\text { ZISKA funds; }\end{array}$ & $\begin{array}{l}\text { CRU } \\
\text { D }\end{array}$ & & $\mathrm{R}$ & $\mathrm{R}$ & $\mathrm{R}$ & $\mathrm{R}$ & $\mathrm{R}$ & $\mathrm{R}$ & $\begin{array}{l}\text { C } \\
R \\
U \\
D\end{array}$ & $\begin{array}{l}\text { C } \\
\mathrm{R} \\
\mathrm{U} \\
\mathrm{D}\end{array}$ & $\mathrm{R}$ & $\mathrm{R}$ \\
\hline $\begin{array}{l}\text { The implementation of the } \\
\text { ZISKA fund raising program }\end{array}$ & & $\begin{array}{l}\text { CR } \\
\mathrm{UD}\end{array}$ & $\mathrm{R}$ & & & & & & & $\mathrm{R}$ & & $\mathrm{R}$ \\
\hline $\begin{array}{l}\text { The program for distributing } \\
\text { ZISKA funds }\end{array}$ & & & $\mathrm{R}$ & $\mathrm{R}$ & & & & & $\mathrm{R}$ & & & $\mathrm{R}$ \\
\hline $\begin{array}{c}\text { Implementation of the ZIS fund } \\
\text { utilization program }\end{array}$ & & & & $\mathrm{R}$ & & & & & & $\mathrm{R}$ & $\begin{array}{l}\mathrm{C} \\
\mathrm{R} \\
\mathrm{U} \\
\mathrm{D}\end{array}$ & \\
\hline Administration management & $\mathrm{R}$ & $\mathrm{R}$ & $\mathrm{R}$ & & $\begin{array}{l}\text { C } \\
\mathrm{R} \\
\mathrm{U} \\
\mathrm{D}\end{array}$ & $\mathrm{R}$ & $\mathrm{R}$ & $\mathrm{R}$ & $\mathrm{R}$ & $\mathrm{R}$ & $\mathrm{R}$ & $\mathrm{R}$ \\
\hline Finance management & & & $\begin{array}{l}\mathrm{C} \\
\mathrm{R} \\
\mathrm{U} \\
\mathrm{D}\end{array}$ & $\begin{array}{l}\mathrm{C} \\
\mathrm{R} \\
\mathrm{U} \\
\mathrm{D}\end{array}$ & & & & & & & & $\begin{array}{l}\text { C } \\
R \\
U \\
D\end{array}$ \\
\hline Human Resources management & & & & $\mathrm{R}$ & & & & $\begin{array}{l}\text { CR } \\
\mathrm{UD}\end{array}$ & & & & \\
\hline Infrastructure management & & & & $\mathrm{R}$ & & $\begin{array}{l}\mathrm{C} \\
\mathrm{R} \\
\mathrm{U} \\
\mathrm{D}\end{array}$ & & & & & & \\
\hline $\begin{array}{c}\text { Public relations and publications } \\
\text { management }\end{array}$ & & & & $\mathrm{R}$ & & & $\begin{array}{l}\text { CR } \\
\text { UD }\end{array}$ & & & $\mathrm{R}$ & & $\mathrm{R}$ \\
\hline
\end{tabular}


Table 5. Application Requirement Based on Business Function

\begin{tabular}{|c|c|}
\hline Business function & Requirements \\
\hline $\begin{array}{l}\text { Supervision, direction, and making decisions on the management of ZISKA } \\
\text { funds to fit syar'i }\end{array}$ & Supervision application \\
\hline Supervision of the management of ZISKA funds & Supervision application \\
\hline $\begin{array}{l}\text { Planning, Implementation, Coordinating in the collection, distribution and } \\
\text { utilization of ZISKA funds }\end{array}$ & Plan and strategy application \\
\hline The implementation of the ZISKA fund raising program & $\begin{array}{c}\text { Collection application (e- } \\
\text { marketing) }\end{array}$ \\
\hline The program for distributing ZISKA funds & Distribution application \\
\hline Implementation of the ZIS fund utilization program & Utilization application \\
\hline Administration management & E-Office application \\
\hline Finance management & Finance application \\
\hline Human Resources management & Human Resources application \\
\hline Infrastructure management & Infrastructure application \\
\hline Public relations and publications management & $\begin{array}{c}\text { CRM Application } \\
\text { Mustahik Complaint Application } \\
\text { Website Profile } \\
\text { ZIS Calculator Application } \\
\text { Muzaki / Donor Registration } \\
\text { Application }\end{array}$ \\
\hline
\end{tabular}

\section{Conclusion}

The design of Enterprise Architecture in LAZISMU D.I.Y produces the applications and entities needed for the development of LAZISMU now and in the future. The requirements of the application and the existing entities are analyzes of the process sequences in TOGAF ADM. Some of the most needed applications consist of financial management applications, utilization applications, web profile applications, and e-marketing. This research still needs to be developed in the realm of implementation and additional stages in TOGAF ADM so that it can produce a complete AE and be able to be implemented in the form of applications that can be utilized by LAZISMU.

\section{Acknowledgements}

This research is supported by The Indonesian Ministry of Research, Technology and Higher Education (RISTEK-DIKTI) research grant no. 109/SP2H/LT/DRPM/2018.

\section{References}

[1] Kementerian Agama, Undang-undang Republik Indonesia Nomor 23 tahun 2011 tentang Pengelolaan Zakat. Indonesia: Government of the Republic of Indonesia, 2011.

[2] Minister of Religion Republic of Indonesia, "Regulation of the Minister of Religion of the Republic of Indonesia Number 52 of 2014 on Terms and Procedures for Calculating Zakat Mal and Zakat Al-Fitr and Utilization of Zakat for Productive Enterprises." Minister of Religion Republic of Indonesia, 2014.

[3] Minister of Religion Republic of Indonesia, "Decree of the Minister of Religion of the Republic of Indonesia Number 333 of 2015 on Guidelines for Granting Permits to Establish Amil Zakat Institutions." Minister of Religion Republic of Indonesia, 2015.

[4] M. Firdaus, I. S. Beik, T. Irawan, and B. Juanda, "Economic Estimation and Determinations of Zakat Potential in Indonesia," Jeddah Islam. Res. Train. Inst., p. 74, 2012.

[5] P. K. S. Badan Amil Zakat Nasional (BAZNAS), Outlook Zakat Indonesia 2017. Badan Amil Zakat Nasional.

[6] S. Pratolo, Good corporate governance: implementasi pada BUMN di Indonesia. Lembaga Penelitian, Publikasi, dan Pengabdian Masyarakat Universitas Muhammadiyah Yogyakarta, 2015.

[7] K. Surendro, Pengembangan Rencana Induk Sistem Informasi. Bandung: Informatika, 2009. 
[8] J. Fahana, "Perencanaan Strategis Sistem Informasi untuk Pengelolaan Guru Sekolah Muhammadiyah," J. Ilm. Tek. Elektro Komput. dan Inform., vol. 4, no. 1, pp. 51-57, 2018.

[9] S. Sumaryanto, "Peranan Sistem Informasi Manajemen Dalam Rangka Peningkatan Dunia Pariwisata Indonesia," J. Akunt. dan Sist. Teknol. Inf., vol. 7, no. 1, pp. 85-97, 2009.

[10]J. Ward and J. Peppard, Strategic planning for information systems, 3rd ed. Chichester West Sussex, England: John Wiley \& Sons, 2002.

[11]R. Hariawan, K. R. S. Wiharja, and E. G. Perdana, "Perencanaan Strategis Sistem Informasi Menggunakan Togaf ADM (Studi Kasus : Bagian Pelayanan Barang pada PT. Pelabuhan Indonesia II)," eProceedings Eng., vol. 1, no. 1, p. 6, 2014.

[12]E. Marlina and B. Nugroho, "Arsitektur Pengembangan Sistem Pengelolaan Jurnal Ilmiah Indonesia menggunakan Framework TOGAF." Pusat Dokumentasi dan Informasi Ilmiah LIPI, pp. 1-16, 2014.

[13] A. Suryadi, "Strategi Perencanaan Dan Penerapan Teknologi Informasi Menggunakan Kerangka Togaf Versi 9: Studi Kasus SMKN XYZ,” Fakt. Exacta, vol. 8, no. 4, pp. 392-399, 2015.

[14]Y. Hutama and A. A. Arman, "Perancangan Enterprise Architecture Menggunakan TOGAF Framework 9.0 dan Content Framework (Studi Kasus BAA Universitas Kristen Maranatha),” vol. 5, no. 1, p. 18, 2014.

[15] R. Rismayanti, "Analisis Penerapan Arsitektur Enterprise Pada Bagian Akademik Perguruan Tinggi (Studi kasus STMIK Bumigora Mataram),” Indones. J. Netw. Secur., vol. 5, no. 2, pp. 26-32, May 2016. 